\title{
RELATÓRIO FIGUEIREDO COMO PROVA DE GENOCÍDIO, MASSACRES E MONSTRUOSIDADES PERPETRADAS CONTRA OS POVOS INDÍGENAS NO BRASIL
}

ADONIAS GUIOME IOIÔ ${ }^{1}$

$U F P A$

Conheci o relatório Figueiredo, quando fui aprovado no Programa de Pós-Graduação em Antropologia (PPGA), na Universidade Federal do Pará (UFPA), na disciplina denominada Etnologia Amazônica, ministrada pela minha orientadora, professora doutora Jane Felipe Beltrão e pela professora doutora Katiane Silva, de março a junho de 2017.

O documento lido e discutido em sala de aula é obrigatório para nós, povos indígenas, porque ele inclui várias temáticas que dizem respeito aos crimes cometidos contra nossas populações. Neste texto, discuto as graves violações de direitos humanos sofridas pelos povos indígenas no Brasil, que estão inscritas no Relatório Figueiredo.

O propósito é compreender o documento que foi registrado, denunciando os responsáveis por diversas irregularidades e crimes contra os povos indígenas. Estes fatos desagradáveis, inesquecíveis, inacreditáveis, impressionantes e monstruosos que ocorreram durante muitos anos com as nações indígenas no Brasil, foram perpetrados tanto pelo Serviço de Proteção aos Índios (SPI), quanto depois, com a criação da Fundação Nacional do Índio (Funai).

O Relatório Figueiredo me auxiliou a refletir a respeito das histórias do meu povo Palikur-Arukwa e, também, sobre a invasão dos europeus. Eu jamais pensava que ia estudar a temática que discute os relatos sobre

\footnotetext{
${ }^{1}$ Pertence ao povo Palikur/Arukwayene, é professor de Língua e Cultura Indígena na Escola Indígena Estadual Moisés Iaparrá, no Oiapoque-Amapá e pesquisador do Núcleo Kusuvwi de Estudos PalikurArukwayene (NUKEPA). Atualmente, é mestrando junto ao Programa de Pós-Graduação em Antropologia (PPGA) da Universidade Federal do Pará (UFPA). Bolsista da CAPES. Endereço eletrônico: adoniasarukwayene@gmail.com.
} 
os massacres dos povos indígenas entre os anos de 1910 e 1967. Quando li esse material pela primeira vez, em casa, como discente indígena do mestrado, para discutir em sala de aula, foi completamente difícil e doloroso. Na verdade, já ouvia esse tipo de relato, mas não desse jeito.

Então, durante a aula para a discussão e debate sobre esse texto, fiquei totalmente mudo, sem jeito, em silêncio, com raiva de sentir aquela dor enorme e profunda. Naquele dia e ainda hoje eu sinto no meu coração essa dor. Fiquei imaginando o sofrimento dos meus parentes naquele tempo, tão triste e sem a saída. Fui ferido como se alguém me desse uma flechada e uma facada no coração, por isso não falei quase nada naquele dia.

Saí de sala com essa tristeza enorme, cheguei em casa com aquela dor que ninguém sabia que eu sentira em aula. Fingia que eu não entendia nada da explicação, porque sentia uma dor tão grande, tão forte que me dava vontade de chorar, eu olhava no rosto dos colegas que estavam falando sobre o texto, mas, eles não sentiam o que eu sentia como Arukwayene naquele dia. Comecei a relembrar os relatos do meu povo dizendo que o SPI era muito melhor que a Funai, que antigamente era bom. Para eles, o SPI é um pai, que cuida, que protege os povos indígenas no Brasil. Fiquei sem palavras para compartilhar com os colegas em sala de aula; fiquei refletindo sobre os acontecimentos entre os povos indígenas.

As dores são grandes que eu trago no sangue dos meus ancestrais dentro do meu coração todos os dias. A luta, a força, a energia, a união e a resistência dos meus antepassados me trouxe até aqui, na universidade, para dizer ao Outro que nós não somos aquilo o que eles pensam, somos, tão somente, pessoas de culturas diferentes. E nós estamos aqui para continuar a luta dos nossos ancestrais, para descontruir desentendimentos, preconceitos, discriminações e racismos, que nós, os indígenas, sofremos desde a invasão dos europeus até os dias atuais. Nós queremos falar de dentro e não de fora; isso significa que nós queremos falar como povos originários deste país. Porque o lugar de fala do Outro é diferente, mas a fala dos indígenas é totalmente diversa, porque nós falamos com nossa força, energia, resistência, respeito, sentimento, tristeza, dor e com a companhia de nossos ancestrais. Além disso, 
também estamos aqui para recontar as nossas histórias para que o Outro possa compreender o nosso modo de viver e modo de pensar.

O Relatório Figueiredo, com seu terrível texto, me ajudou muito para me esforçar cada vez mais nos meus estudos, não somente para mostrar à sociedade que somos capazes de aprender qualquer língua e conhecimentos científicos, mas também que nós temos conhecimentos milenares, sabedorias que podemos compartilhar, sim, com os não indígenas, portanto, com respeito, com reciprocidade, como seres humanos e não como inimigos.

Afinal, o que significa Serviço de Proteção aos Índios (SPI)? Qual é o papel do Serviço de Proteção aos Índios? O SPI foi criado em 1910, por Marechal Candido Mariano da Silva Rondon, como Serviço de Proteção aos Índios. De acordo com a Comissão Nacional da Verdade (CNV), este órgão do Estado brasileiro era responsável pela proteção e pela assistência aos povos indígenas em inúmeros campos da vida cotidiana, como saúde, educação, demarcação das terras indígenas, e também tinham a função de pacificar os indígenas, atendê-los com recursos, inseri-los no rumo do processo civilizatório, ou seja, integrar os povos indígenas à sociedade nacional, preparando-nos para o trabalho em novas propostas. Todavia, não cumpriram os seus compromissos e suas responsabilidades como protetores. Nosso bem-viver foi destruído o quanto eles puderam e desejaram nos integrar, esquecendo que temos pertença.

As barbaridades que estão escritas no Relatório Figueiredo referendadas pelo que apurou a Comissão Nacional da Verdade são monstruosas, dolorosas. Algumas se destacam, por exemplo: funcionários públicos vendiam as crianças indígenas indefesas para servir aos instintos de indivíduos desumanos que abusavam sexualmente delas; torturas contra crianças, jovens e adultos, a partir de monstruosos e lentos suplícios, a título de ministrar justiça. O autor do Relatório narra que a crueldade foi tanta que, os funcionários do SPI, chegaram a crucificar pessoas indígenas, e castigos físicos eram rotina nos postos indígenas, independente de idade e sexo. Os espancamentos faziam parte do cotidiano e podiam ocasionar a invalidez ou a morte (BRASIL, 2013 [1967]).

Alguns agentes do SPI estavam cheios de ódio e eram perversos a ponto de obrigarem as pessoas indígenas a castigarem seus queridos 
pais. Imagine então, ver um filho espancar a própria mãe, irmão bater em irmã e assim sucessivamente. Isso era a ordem dos chefes poderosos dos postos do SPI e, se a pessoa se recusasse a obedecer, a ordem era castigar o rebelado, o qual poderia até mesmo perder a vida.

A tortura no "tronco", encontrada pelo procurador Jader de Figueiredo na $7^{\mathrm{a}}$. Inspetoria, era extremamente feia e amargurante. 0 castigo era monstruoso, porque a pessoa castigada sofria o esmagamento dos tornozelos, que eram colocados entre dois esteios enterrados juntos em ângulo agudo. As pontas, ligadas por roldanas, eram aproximadas de forma lenta e contínua, e ninguém podia ajudar a pessoa castigada. Com os tornozelos esmagados, a pessoa não mais podia se por em pé (BRASIL, 2013 [1967]).

Na verdade, o SPI não respeitava, aliás, jamais respeitou o indígena como humano; considerava os homens e as mulheres indígenas como animais de carga, e o trabalho que desenvolviam deveria ser revertido em benefício dos funcionários que obrigavam os indígenas a trabalhar dessa forma. Portanto, principalmente no caso das mulheres, as condições eram desumanas e revoltantes. Em alguns postos do SPI, obrigavam-se as mulheres parturientes a trabalhar na roça logo depois do parto, e elas eram proibidas de levar consigo o recém-nascido. É inacreditável como o tratamento da mulher era inferior ao dos animais. Como se o indígena fosse um irracional, classificado, como diz o procurador Figueiredo, de maneira muito inferior aos animais (BRASIL, 2013 [1967]).

O tamanho da corrupção e dos delitos cometidos por agentes do Serviço de Proteção aos Índios e a anarquia que imperava no órgão era de estarrecer. Os denunciados tinham por objetivo, segundo meu ponto de vista, exterminar os povos indígenas no Brasil para que pudessem distribuir nosso patrimônio entre eles, especialmente as terras habitadas pelos parentes. Penso que queriam as terras para que pudessem cavá-las com as suas máquinas, destruindo-as atrás de ouro, poluindo rios, lagos e igarapés com veneno.

Essa violência direta do Estado ficou "embrulhada" e silenciada por muitos anos, por conta de negligência e irresponsabilidade dos governantes, os quais deixaram de fiscalizar a corrupção que existia no país e a violação de direitos dos que são submetidos à política indigenista. (BRASIL, 2014). 
Hoje, a minha interpretação como indígena do povo Palikur-Arukwa é que essas duas instituições governamentais que foram inventadas, que teriam sido inventadas como uma forma de proteger os povos originários, nunca pretenderam realmente nos proteger; muito pelo contrário: na verdade, os seus propósitos foram dominar, fraudar, tomar, vender e enriquecer com as terras dos povos originários, além de exterminar os povos indígenas de modo geral.

O Brasil jamais protegeu e respeitou o seu povo - e menos ainda os povos indígenas. Muitas instituições, sabemos hoje, são corruptas, roubam o povo, comportam-se como monstros destruindo a humanidade, não respeitando nem as leis que elas mesmas elaboraram.

Hoje, vejo nas mídias o que está acontecendo com os povos indígenas neste país: muitas lideranças indígenas foram assassinadas por madeireiros, mineradores, fazendeiros. Muitos projetos são implantados sem consultar os povos indígenas. Isso é um desrespeito muito grande conosco. Muitos dos meus parentes que moram próximos das cidades sofrem preconceito, descriminação e racismo. E nossas lideranças, quando vão para Brasília, são desrespeitadas pelos deputados federais, senadores e presidente da República. São recebidos com bala de borracha e com spray de pimenta. Isso é um absurdo. Cadê as leis que eles criaram para defender os povos originários?

Ainda dizem - e nós ouvimos falar nas mídias, nas ruas, nas instituições estaduais e federais - que nós indígenas somos preguiçosos, selvagens, bárbaros, entre tantas outras bobagens ofensivas. Quero dizer a todos os brasileiros que nós indígenas não somos selvagens. Selvagens são aqueles que não respeitam os outros, que poluem nossas águas, tomam nossas terras. É isso que significa ser selvagem, é isso que penso eu, como indígena que sou.

Esses governantes poderosos tentaram nos excluir deste país e, atualmente, continuam com ideia para nos amansar e "pacificar", a nós, povos indígenas. Essa "pacificação" é uma guerra desde a invasão dos portugueses. Mas eles não vão conseguir vencer, porque nós somos fortes e resistentes. Sempre estivemos em pé para defender o que temos por direito, como humanos que somos, e povos indígenas deste país.

Como indígena, pergunto para os governantes: por que vocês estão fazendo isso conosco, os povos indígenas? Por que vocês querem tomar 
as nossas terras, apesar de termos muito pouco diante do que se tínhamos no passado? Por que vocês querem nos exterminar? E onde estão as leis que vocês criaram? Onde esconderam o respeito de homens civilizados que dizem ser? A ética do homem branco foi escondida onde? Será que vocês são gente de verdade, como nós somos? Vocês já conseguiram dominar este território de modo geral, o que vocês mais querem além disso? Vocês querem contaminar as terras? Vocês querem destruir a humanidade? Vocês querem poluir as águas? Vocês sabem criar uma nova terra? Vocês querem morrer de fome? Vocês querem criar uma guerra por falta de água boa? É isso que vocês querem? O que vocês pensam hoje para o futuro das gerações? O que vocês pensam para os seus filhos e netos?

Como indígena, vejo que os dois órgãos têm as mesmas funções, mas não cumpriram a tarefa de proteger os povos indígenas no Brasil. A Fundação Nacional do Índio (Funai) conseguiu diminuir os massacres, as agressões diretas dos não indígenas, a invasão dos garimpeiros em algumas terras indígenas, e realizar a demarcação e homologação de algumas das Terras Indígenas de diversas etnias no Brasil. Contudo, precisa melhorar cada vez mais para defender os direitos dos povos indígenas de acordo a Constituição brasileira de 1988, e caminhar celeremente em direção ao reconhecimento de outras terras indígenas. Porque ainda existem muitos direitos não observados, apesar de inscritos na Constituição.

Quando será que os governantes vão acabar com a corrupção no Brasil para melhorar o país? Porque hoje ainda existem muitas pessoas sofrendo de fome nas ruas, sem nada para o sustento de suas famílias e nem residências para morar. As pessoas continuam lamentado, gritando para que os governantes compreendam e respeitem as populações. Continuam realizando inúmeras greves para defender os seus direitos. $\mathrm{E}$, muitas vezes, são agredidos pelos policiais federais e pelo exército - e isso é uma vergonha para os governantes do Brasil. Sempre dizem que os povos indígenas que são selvagens, mas afinal quem é selvagem?

Esses brancos gulosos conseguiram tudo o que eles queriam eles: invadiram as nossas terras, conseguiram exterminar inúmeros povos originários destas terras e destruíram todos os seus bens, tanto os patrimônios culturais materiais, quanto patrimônios culturais imateriais. 
E continuam nos pressionando para tomar as terras que eles mesmos demarcaram e homologaram para os povos indígenas do Brasil. Criaram a lei para que todos seres humanos possam ter os seus direitos iguais, mas os próprios autores não a respeitam.

Hoje, as dores dos povos indígenas são cicatriz símbolo que marca o coração das pessoas de cada grupo tradicional: infinita, sem perdão e jamais terá cura, porque não sara. Porque olhem o tamanho dos crimes cometidos pela ação colonial e, ainda hoje, continuam com a ideia de exterminar os povos indígenas e tomar as suas terras.

Do meu ponto de vista como indígena da etnia Palikur-Arukwa, os movimentos indígenas no Brasil ainda estão fracos. Precisa-se unir cada vez mais, porque unidos, jamais seremos vencidos. Precisamos buscar novas alternativas para continuar lutando para defender as nossas terras, nossas famílias, nossos filhos, nossos direitos e as nossas culturas. Precisamos mostrar para a sociedade não-indígena que temos capacidades, e também que somos fortes e unidos. Desistir jamais, porque nós somos guerreiros.

Gostaria de dizer aos parentes que nós precisamos respeitar e valorizar cada vez mais as nossas lideranças, porque são eles que estão lutando para que nós estudantes e comunidades continuemos a defender os nossos direitos relativos à terra, educação e saúde. Pelo menos eu acredito que a gente consiga resistir a todas as investidas que 0 capitalismo nos impõe, para que juntos possamos nos fortalecer com ética, seriedade, respeito à comunidade e à verdade, sem mentiras. Espero que não nos vendamos aos que querem nos ver extintos, pois temos um passado de luta contra as ideologias de exploração do branco. Convido todos vocês parentes para nos unirmos, porque a união nos tornará mais fortes e resistentes.

Parentes, sempre lembro dos nossos ancestrais que lutaram pela sobrevivência, para preservar e defender as culturas, as línguas, as terras, e contra o extermínio. Essas histórias, escritas em vários livros e relatórios no Brasil, nos ensinam sobre as vidas dos nossos ancestrais que lutaram muitos anos, décadas e séculos, e que foram caçados, massacrados, envenenados como se fossem animais. É preciso ler para combater o inimigo. 
Nossos ancestrais foram considerados os piores dos animais do mundo, mas resistiram com sangue, suor e muita luta, e nós estamos aqui escrevendo capítulos de nossa história: novas páginas, novos rumos, novas perspectivas. Pensem, não podemos desistir, eles jamais desistiram, porque eles eram/são grandes guerreiros, fortes e incansáveis. Porque nós nascemos para existir e por isso faz-se necessário resistir. Lembro todos os dias das histórias dos nossos ancestrais e carrego, pelo que conheço, enorme dor no meu coração, na minha alma e na minha memória.

Finalizo a minha fala escrita com a enorme tristeza que carrego, hoje como estudante na Universidade Federal do Pará, cursando mestrado. E afirmo, quando eu ouvi essas histórias lagrimei muito naquele dia e continuo lagrimando. Além disso, os nossos parentes, ainda hoje, sofrem nos outros estados: muitas lideranças foram assinadas por defender as terras onde habitam, são os parentes de outros estados lutando e tendo seu sangue derramado por defender os nossos diretos. Por isso, eu me esforço cada vez mais nos meus estudos para mostrar à sociedade não indígena que nós temos capacidades e conhecimentos que nós adquirimos dos nossos ancestrais, e que as nossas culturas estão vivas, porque elas estão no nosso sangue, nas nossas almas e nos nossos corações. Vamos nos unir para preservar as nossas culturas como seres humanos e como povos originários desta terra. Quero dizer para meus queridos parentes e amigos que nós, povos indígenas, avançamos, mas precisamos ir mais adiante para melhorar a educação, a saúde e defender as nossas terras e as nossas culturas.

\section{Referências documentais}

BRASIL. Relatório da Comissão Nacional da Verdade. V. II. Comissão Nacional da Verdade (CNV). Brasília, 2014. Disponível em: <http://www.cnv.gov.br/images/pdf/relatorio/volume 2 digital.pdf $>$. Acesso em 14 mar. 2017.

BRASIL. Relatório Figueiredo: documento na íntegra. 2013 [1967]. Disponível em: <http://racismoambiental.net.br/2013/06/02/relatorio-figueiredo-documento-na-integra-7-milpaginas-pdf-pode-agora-ser-baixado/>. Acesso em 10 mar. 2017. 
Recebido em: 09/06/2018 * Aprovado em: 13/12/2018 * Publicado em: 29/12/2018 